\title{
MUYRAKYTÃ OU MUIRAQUITÃ, UM TALISMÃ ARQUEOLÓGICO EM JADE PROCEDENTE DA AMAZÔNIA: UMA REVISÃO HISTÓRICA E CONSIDERAÇÕES ANTROPOGEOLÓGICAS.
}

\author{
Marcondes Lima da COSTA ${ }^{(1)}$, Anna Cristina Resque Lopes da SILVA ${ }^{(1)}$, \\ Rômulo Simões ANGÉLICA ${ }^{(1)}$
}

RESUMO - Aparentemente os primeiros dados documentados sobre a história dos muiraquitàs, ainda que inferidos, surgem com Orellana, tido como o primeiro explorador a navegar o rio Amazonas rio baixo, ainda em 1542, quando teria combatido com indias guerreiras valentes, sem maridos, as quais denominou de Amazonas. Posteriormente De la Condamine em sua viagem ao longo deste rio, em 1735, descreve amuletos batraquianos em pedras verdes semelhantes a jade. Spix e Martius escrevem sobre pierres divines como pingente batraquiano em madrepérola e com nome de muraquêitã. Antigos escritos de Mauricio Heriarte de 1662 descrevem amuleto com termos similares: baraquitãs, buraquitãs, puúraquitan, uuraquitan e mueraquitan. Finalmente Barboza Rodrigues em 1875 emprega o termo muyrakytã modificado por Barata em 1954 para muiraquità, que entende como artefatos em forma de sapo confeccionados em pedra verde, com dois furos laterais. Teriam sido usados pelos povos Tapajó/Santarem e Conduri, que habitavam o Baixo Amazonas até a chegada do colonizador europeu, que os dizimou. Para elaborar os muiraquitãs acredita-se que esses povos utilizavam instrumentos engenhosos, mas principalmente muita paciência e habilidade. Os estudos mais recentes mostram que o maior centro produtor estava na região, da mesma forma como a fonte da matéria-prima e não na Ásia como suposto pelos historiadores. Eram utilizados como amuletos, símbolos de poder, e ainda como material para compra e troca de objetos valiosos. Sobre eles há muitas lendas e mitos sempre envolvidos com as indias Amazonas, extintas ou lendarias.

Palavras-chave: Muiraquitã, muyrakytã, Amazonas, Amazônia, história, lendas

Muyrakytã or Muiraquitã, an Archaeological Jade Talisman Coming from Amazonia: Historical Review and Anthropogeological Implications

ABSTRACT - The first indirect written informations about the muiraquitàs, are related to Orellana, who traveled the Amazon river for the first time downstream in 1542 and mentioned presence of the Amazonas Indians, living without husbands and act as brave fighters. De la Condamine during his travel in 1735 along the Amazonas discribed frogshape amulet made of greenstone like jade used by Amazonas. Spix and Martius written about pierres divines, and used the name Muraquêitã for frogshape pendant made of motherpearl. However older writtens of Mauricio Heriarte used therms close to muiraquitã: baraquitãs, buraquitãs, puúraquitan, uuraquitan, mueraquitan. Finally Barboza Rodrigues at 1875 brought the name muyrakytã to well acept therminology which was reinforced by Francisco Barata in 1954 as muiraquità. Barata defines as a frogshape artifact sculptured in greenstones, jade. Muiraquitã is of tupi origin meaning using frogshape pendant. They were used by Indians of Tapajó/Santarém and Conduri Tradition which lived at the Lower Amazon region until the first contacts with the European colonizators. To make the muiraquitãs, artifact of high finnished carving, one presumes that the Indians used ingenious processes, meanwhile the most important was patience and ability. The most important centre of frogshape artifact carving was the Lower Amazon. Although supposed to be Asia, the source of the raw material must have been the Amazonia. The muiraquitã were used as amulet and symbol of power between the chiefdoms in the Amazon region during its time. About them there are several legends and myths always connecting with the Amazonas fighters of Orellana.

Key-words: Muiraquitã, muyrakytã, Amazonas, Amazonia, history, legends

(1)Centro de Geociências/Universidade Federal do Pará, Belém-PA, Brazil 
Os Europeus Deparam-se com as Guerreiras Amazonas e os Muiraquitãs

\section{Orellana e as Amazonas}

Em 1499, cinco anos após a assinatura do Tratado de Tordesilhas, o navegador espanhol Vicente Yañez Pinzón era o primeiro navegador europeu a registrar sua passagem pela costa nordeste do que hoje conhecemos como Brasil, ainda um mundo desconhecido dos europeus e asiáticos. Nesta viagem navegou pelas águas da desembocadura do rio Amazonas, denominando-a de mar de água doce (Mar Dulce). Pedro Álvares Cabral, navegante português, que chegou ao Brasil um ano mais tarde, em abril de 1500, tornou-se o descobridor do Brasil. Desde então, o Brasil, e em especial a Amazônia, foi visitada por viajantes, exploradores, aventureiros, missionários e posteriormente pesquisadores de ciências naturais. Um dos primeiros e o mais destacado explorador foi Francisco de Orellana, que entre 1540 e 1542, desceu o rio Amazonas em toda sua extensão, de Quito até o Oceano Atlântico. Nessa expedição Orellana, através de seu cronista Frei Gaspar de Carvajal, informa que encontrou indias guerreiras, sem maridos, as Amazonas (do grego: amazos $=\mathrm{sem}$ seios), com que revidaram o combate com grande bravura. Segundo ele as Amazonas são muito alvas e altas, com o cabelo muito comprido, entrançado e enrolado na cabeça. São muito membrudas e andam nuas em pelo, tapadas as suas vergonhas, com os seus arcos e flechas nas mãos, fazendo tanta guerra como dez indios. Mas os índios não falavam de Amazonas, e sim Ikamiabas (mulheres sem maridos) que habitavam o rio Nhamundá ou Yamundá (Monteiro, 1997).

\section{De La Condamine e as Pedras Verdes}

No século XVIII a Europa, preocupada com a América do Sul, envia uma série de pesquisadores e cientístas. Entre estes destaca-se Charles-Marie De La Condamine, que, de 1735 a 1745 , percorreu o rio Amazonas, e ficou impressionado com as pedras verdes que encontrara em posse dos índios da região do Baixo Amazonas (essa região correspondente hoje àquela ocupada pelas cidades de Óbidos, Faro, Nhamundá e Santarém, de domínio dos povos indígenas os Tapajó). De La Condamine foi assim um dos primeiros a registrar por escrito o uso de pedras verdes pelos índios. Essas pedras eram conhecidas também como pedras das amazonas, uma alusão às indías guerreiras descritas por Carvajal. Antes de aí chegar, De La Condamine fora previamente informado da ocorrência dessas pedras. Ainda no Alto Amazonas um ancião, cujo avô teria visto as Amazonas, lhe relatou sobre as pedras verdes e as Amazonas. Segundo De Le Condamine, história semelhante era contada por toda parte. E assim insistiu em ver in loco as pedras verdes e as amazonas. De La Condamine (1992) em seu livro Voy- 
age sur l'Amazone menciona "entre os Tapajós, encontramos hoje, mais facilmente do que alhures, as pedras verdes conhecidas com o nome de pedras das Amazonas, cuja origem é ignorada e que foram muito procuradas outrora, por causa das virtudes que lhes eram atribuidas na cura do cálculo e da cólica renais, bem como da epilepsia". Portanto, só a partir do século XVII é que os povos da região começavam a relacionar as lindas pedras verdes com a fabulosa história das indias guerreiras, as amazonas, de Orellana.

\section{Origem da Denominação Muyrakytã ou Muiraquitã}

Embora a região dos Tapajó tenha sido visitada e vivida por missionários, navegantes e pesquisadores, todos eles apenas faziam vagas referências às pedras verdes, sem fazer uso de qualquer outro termo específico. Spix e Martius, que aqui estiveram de 1817 e 1820, registraram em sua obra Reise in Brasilien, a designação em tupi das pierres divines, que tanto perseguiram, e uma única vez se referem a Muraquêitã (Barata, 1954) talhado em madrepérola. Barata (1954) ainda reconhece que é quase impossivel precisar a época em que surgiu o termo atual muiraquitã, já que a maioria dos missionários e cientistas da época, na sua convivência com as tribos, não teria se preocupada com a grafia correta dos termos empregados pelos índios para designar as pedras verdes. Para Barata (1954), a primeira referência à grafia, remonta ao manuscrito de Maurício de Heriarte, em 1662, grafado como baraquitãs e buraquitas. Em 1759, o padre José de Moraes, menciona puúraquitan; $e$ o bispo Frei João de S. José de Queiroz, de 1762-1763, uuraquitan. É interessante frisar que no período de todo século XVI até o final do XVIII, nem missionários e nem cronistas fizeram referências ao uso das pedras verdes, só vindo acontecer com De La Condamine. Grafia semelhante a muiraquitã surge impressa pela primeira vez em 1873 no livro do Cônego Francisco Bernardino de Souza "Lembranças e Curiosidades do Valle do Amazonas", como mueraquitan, e logo depois na edição de Viena do manuscrito de Heriarte (1874), encomendado pelo Barão de Porto Seguro. Rodrigues (1875), em seu "Relatório sobre o Yamundá" refere-se a muyrakytã.

Ainda em 1879 Smith (1879) em seu livro, Brazil - The Amazons and the Coast, influenciado por Rodrigues (1875), refere-se às pedras verdes, com formas zoomormas (pássaros e animais, e ainda formas cilindricas e contas ), denominadas de muirákitans, encontradas na região do Tapajós, terra habitada pelos indios Tapajó, da nação Tupinambás e sempre conectadas com a história das amazonas.

Para Barata (1954) o termo muiraquitã popularizou-se a partir da obra de Barboza Rodrigues (Rodrigues, 1899), "O Muyrakytã", publicada em Manaus em 1889 e reeditada no mesmo ano no Rio de Janeiro. O termo muiraquitã 
populariza-se exatamente na boca dos civilizados e semicivilizados, quando os índios portadores desse artefato lítico já estavam praticamente extintos, manifesta-se Barata (1954).

A literatura antropológica e arqueológica sobre a Amazônia Brasileira registra a partir do final do século XIX muitas lendas sobre os muiraquitãs e as amazonas. Sua beleza associada às lendas e poderes místicos despertaram a curiosidade dos viajantes, que levaram muitas peças de muiraquitãs para Europa. Hoje encontram-se em museus e com colecionadores particulares. No Brasil algumas peças estão com particulares, quatro exemplares no Museu Paraense Emilio Goeldi (MPEG), na cidade de Belém do Pará, e cinco no Museu Paulista de Arqueologia e Etnologia (MAE) da Universidade de São Paulo (USP), em São Paulo-SP. Se no século passado eram raros, hoje são raríssimos e valiosos e de difícil acesso. Suas lendas, seu valor como amuleto e sua raridade os tornaram muito cobiçados.

\section{O Legado Escrito}

Muito tem sido escrito sobre os muiraquitãs. Das primeiras obras se destacam as de De La Condamine (1944, 1992) Voyage sur l'Amazone (1735-1745) e de von Martius (1867), Beiträge zur Ethnographie und Sprachenkunde Amerika's zumal Brasiliens.

Barboza Rodrigues deixou um grande legado através dos trabalhos Exploração do Valle do Amazonas, de
1875; Exploração do Rio Jamundá, de 1875; O Muyrakytã - Estudo da origem Asiatica da civilisação do Amazonas nos tempos prehistóricos, de 1889; O Muirakytã e os Ídolos Symbólicos, de 1899 (Rodrigues, 1875, 1899; Barata, 1954). Este último teve ampla divulgação e repercussão. Ele propunha que as pedras verdes tivessem sido trazidas da Ásia pelos primeiros imigrantes que povoaram a América. Enfrentou duras críticas, principalmente após a descoberta de jade a nephrita no Brasil. Mas simultaneamente a ciência americanista, por outros meios, concluía que foram asiáticas as primeiras correntes humanas a povoarem a América, fortalecendo assim a idéia de Rodrigues.

Novos trabalhos sobre muiraquitãs foram publicados ainda ao final do século XIX e inicio do XX como Investigações sobre a Archeologia Brasileira, de 1885, por Ladislau Netto (Netto, 1885); Archeologia comparativa do Brazil, de 1906 , por Heinrich von Ihering (Ihering, 1904; 1906).

No trabalho Sobre o Jade no Brasil, de 1932, Luciano Jacques de Moraes (Moraes, 1932), refuta origem asiática para o muiraquitã, tendo em vista a ocorrência de jade a nefrita no Brasil.

Koehler-Asseburg (1951) em seu trabalho O Problema do Muiraquitã, discute, com base em ampla pesquisa bibliográfica, aspectos históricos, etnográficos, uso, procedência, composição, aspectos físicos, simbolismo e lendas e ainda avalia o 
acervo do Museu Paulista.

$O$ Muiraquitã e as Contas dos Tapajó, Frederico Barata (Barata, 1954), um trabalho exaustivo e critico que propõe como muiraquitãs os artefatos em pedra verde com forma batraquiana com furos laterais duplos, não visiveis pela parte frontal.

Embora não enalteça os muiraquitãs, mas os artefatos précolombinos de pedras verdes (green stones, the amazon-stones, pierres vertes), entre os quais inclui os muiraquitãs, Boomert (1987), Gifts of the Amazons: "green stone" pendants and beads as items of cerimonial exchange in Amazonia and the Caribbean, è o mais recente trabalho $\mathrm{e}$ envolve ampla cobertura bibliográfica e uma discussão geográfica mais abrangente, incluindo estudos mineralógicos. Ele, porém, não dá a dimensão que os muiraquitãs representaram ou representam hoje para a Amazônia, mas é um dos únicos trabalhos a mostar quão importante e ampla foi a cultura da pedra verde na forma batraquiana (frog-shaped) $\mathrm{em}$ todo regiào setentrional da América do Sul (Caribe e Amazônia).

\section{O Que São Muiraquitãs}

Rodrigues (1899) entende que os muiraquitãs sejam artefatos confeccionados em pedras verdes, nefrita, com diferentes formas (zoomorfas, especialmente batraquianas, cilindricas, fusiformes, etc.), encontradas na região de Óbidos, no Baixo Amazonas. É o que foi registrado no Dicionário da Lingua Portuguesa no Brasil - Novo Dicionário Aurélio
(Ferreira, 1997), que descreve o muiraquitã como "artefato talhado em nefrita, com formas diversas, algumas vezes de batráquios, quelônios, serpentes. etc., que tem sido encontrado no baixo Amazonas, e ao qual se atribuem virtudes de amuleto"; São conhecidos também como pedra verde, pedras das amazonas.

Barata (1954) admite apenas as formas batraquianas com duplos furos laterais como verdadeiros muiraquitãs. No presente trabalho entende-se como muiraquitã a forma batraquiana de Barata (1954), que é a de maior aceitação, esculpida $\mathrm{cm}$ mincrais c rochas verdes (Fig. 1). Estender o termo a outros artefatos líticos abundantes na região, e sem o esmero dos muiraquitãs, seria colocá-los no lugar comum dos demais (Fig. 2). A reconstituiçao histórica destes artefatos é dificultada pelo fato de que os povos colombinos da Amazônia, que os confecionaram e usaram, não fizeram uso da escrita. Até o próprio termo muiraquitã pode ser questionado, captado apenas pelos exploradores europeus, não sendo um legado de próprio punho dos nativos. Para Barata o termo muiraquitã é "nome tupi dado ao objeto em época posterior à conquista da Amazônia e, portanto, sem a menor correspondência com a antigo e legitimo conceito indigena, que talvez nos seja impossivel conhecer". Os registros escritos após a chegada dos europeus à Amazônia são frutos em grande parte de lendas contadas por ribeirinhos e exploradores. Boomert (1987) deixa entender que muiraquitãs são apenas as formas batraquianas do 
Baixo Amazonas, que são artisticamente diferentes das demais regiões (Caribe, indias Ocidentais, Venezuela, Guiana, Suriname). Boomert assim descreve um muiraquitã do Baixo Amazonas: The most elaborately sculptured specimens have more or less triangular heads which are clearly separated from the body. Toes, mouth and legs are seldomly indicated. The provision for suspension typically consists of two connected drillings, one lateral and one dorsal, on either side.

\section{Etimologia}

Rodrigues (1875) usou o termo com a grafia Muyrakytã. Embora seja ainda motivo de controversa a etimologia do termo muiraquitã, hoje aceita-se como verbete de origem tupi [mïraki'tã], tipicamente amazônico. Correntemente é grafado Muiraquitã, conforme consta no trabalho de Barata (1954). Em seu trabalho, com base em carta de Max Boudin, conclui que o termo em tupi seria pu'ir-a(w)ki(i)tã ou mu'ir-a(w)ki-(i)tã [pu'ir ou $m u^{\prime} i r=$ missangas, contas, enfeites, etc.; $a(w) k i=$ mexer, usar, tocar; $i t \tilde{a}=$ espécie de sapo ou rã. A grafia muiraquitã já está consagrada no Novo Dicionário Aurélio, da lingua portuguesa no Brasil.

\section{Ocorrência Geográfica e Etnografia}

Os principais documentos e publicações sobre os muiraquitãs (Rodrigues, 1899; Koehler-Asseburg, 1951; Barata, 1954; s/d; Boomert, 1987) mostram que a maioria dos muiraquitãs provém do Baixo Amazonas, especialmente da área do rio Tapajós, ocupada pela atual cidade de Santarém e outras vilas e cidades próximas (Alter do Chão, Belterra) (Fig. 3). Nesta região desenvolveu-se uma das culturas mais avançadas do Brasil, a cultura/tradição Tapajo/Santarém e Konduri, dizimadas pelo contato com a arrogância e brutalidade do colonizador europeu a partir do século XVI. A cultura Tapajó deixou um grande legado em cerâmica policrômica. Há notícias de ocorrências de muiraquitãs no rio Nhamundá, nos municípios de Óbidos e Faro, também no Oiapoque, ilha do Marajó, às proximidades de Manaus e no alto Rio Negro (Fig. 3), que não especificam se a forma é batraquiana ou não. Em Faro (Koehler-Asseburg, 1951) encontrou muiraquitãs em nefrita ou jadeita como amuletos, muito estimados pelos indios Uaboi, por estes fabricados (habitam o rio Nhamundá, outrora habitado pelas Amazonas, segundo a lenda, que delas teriam aprendido a arte de confecção). Todas as lendas são unânimes ao relacionar a região Trombetas/ Nhuamundá, próxima a Santarém (Fig. 3), como a região onde habitaram as guerreiras Amazonas. A concentração de peças na área do Tapajós, em área geográfica das culturas TapajóSantarém e Konduri, encontrada ao tempo de sua extinsão, é uma forte evidência da relação entre estes povos e os muiraquitãs. Embora todas as crônicas e trabalhos mostrem essa relação, Barata (1954) informa, com base em pesquisas arqueológicas, que os Tapajó não mais utilizavam nefrita ou jadeita em seus trabalhos líticos, nem um só muiraquitã 


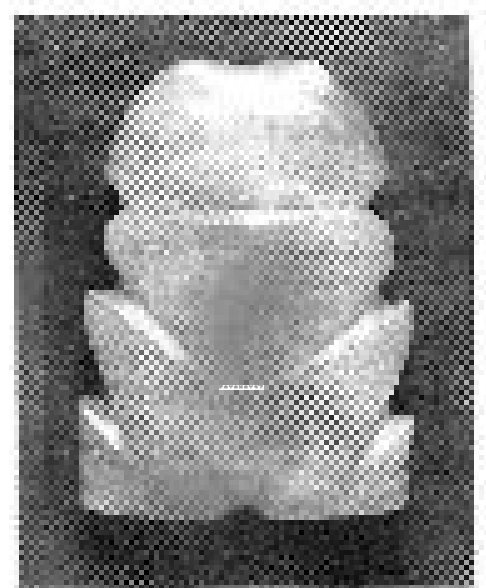

A1

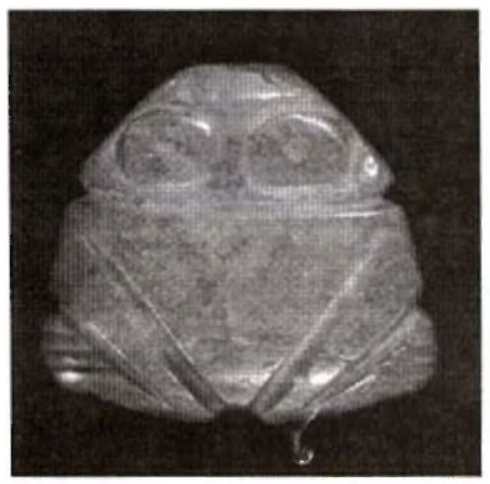

B1

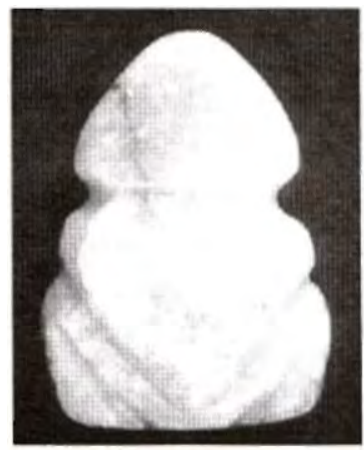

C1

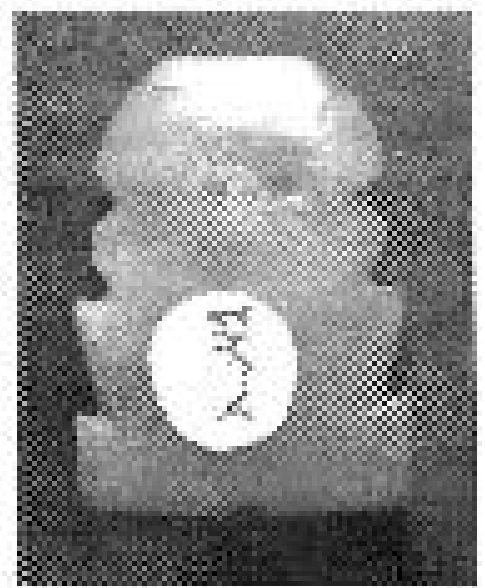

A2

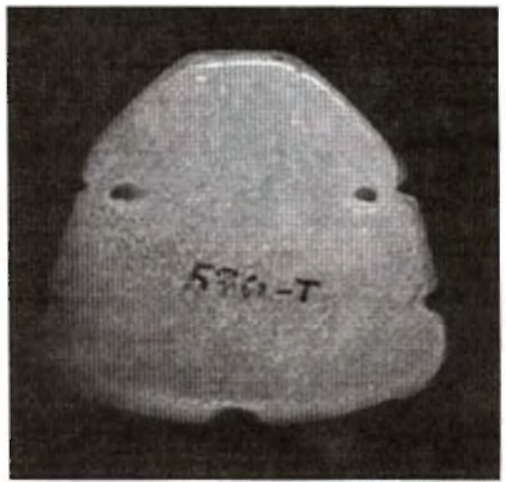

B2

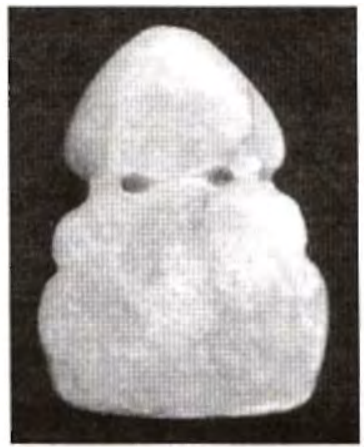

$\mathrm{C} 2$

Figura 1. O muiraquitã segundo Barata (1954) $\mathrm{cm}$ pedra verde com furos laterais. Vistas frontal e posterior. Proprietários do acervo: Al c A2) MAE, São Paulo; B1 c B2: MPEG, Belém; C1 E C2: profa. Amarilis Tupiassu, Belém. 


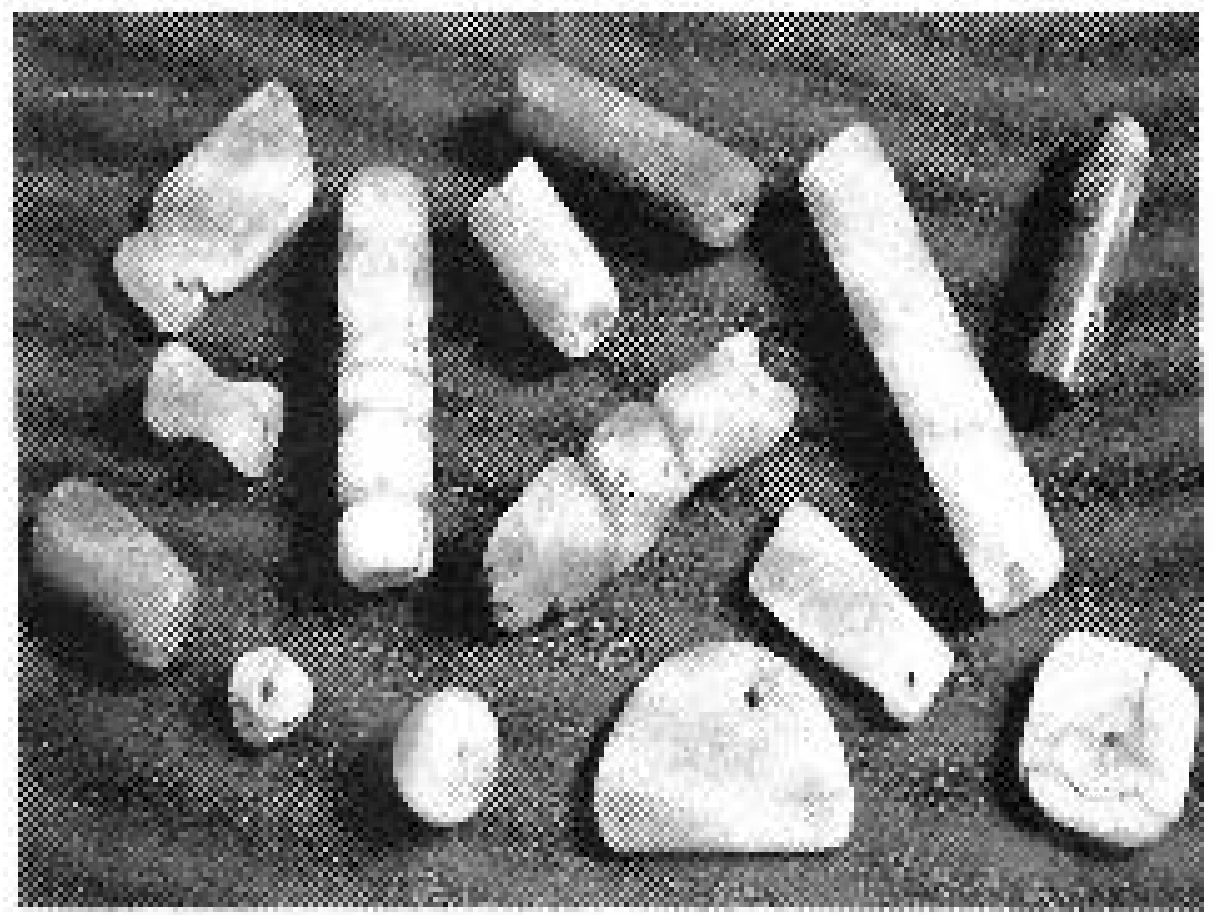

Figura 2. Contas e formas cilíndricas confeccionadas em jade (nefrita) do Baixo Amazonas. Accrvo do MPEG, Belém.

desse material foi encontrado $\mathrm{em}$ Santarćm e adjacências, para ser capaz de comprovar a proveniência local. Peças batraquianas foram encontradas na Venezucla, Guiana, Índias Ocidentais (Antilhas, Mar do Caribe), America Central Continental, Colômbia, Venezuela, Guiana, Guiana Francesa, Suriname (Palmatary, 1960; Boomert, 1987). Segundo eles isto demonstra a estreita conexão destas áreas com a Amazônia Brasileira. Pelo exposto verifica-se que os muiraquitãs (formas batraquianas) foram encontrados principalmente no Baixo Amazonas, em área hoje ocupada por Santarém, Óbidos e Faro e seus rios principais como Tapajós e TrombetasNhamundá (Yamundá). Além da Amazônia Brasileira cles são encontrados em países vizinhos de domínio Amazônico, da América Central e İndias Ocidentais. No Baixo Amazonas estes artefatos foram encontrados com os índios Tapajó e Uaboi.

\section{Material Constituinte dos Muiraquitãs}

Todos relatos históricos (livros e crônicas) relacionam os muiraquitãs às pedras verdes, que Charles-Marie De La Condamine, no século XVIII, já correlacionara com jade: " ne different ni en couleur, ni en durete du jade oriental; elles resistent a la lime et on n'imagine pas, par quel artifice les anciens Américains ont pû les tailler et leur donner diverses figures d'animaaux" (Koehler-Asseburg. 
1951). Nessa época sabia-se que as esculturas de pedras verdes (green stones, pedra do Amazonas, Amazonstone, Amazonstein, pierres vertes, piérre divine da América, Europa e Ásia), as de maior valor, eram elaboradas normalmente em jade a nefrita. Netto(1885) ainda comenta a preferência dos povos antigos pelas pedras verdes, da mesma forma que os povos atuais, ditos civilizados, sao atraidos pelas mesmas pedras, a exemplo da esmeralda, turmalina, safira, por que não acrescentar malaquita, crisoprásio, turquesa.

Os muiraquitãs e outros artefatos do Baixo Amazonas, foram esculpidos em nefrita, ou seja em jade, além de talco, amazonita, chloromelanita (variedade de jadeita), quartzo, diorito, dolerito, serpentina, argila, mas nunca resina (Rodrigues, 1875; Koehler-Asseburg, 1951). Os pingentes em formas batraquianas encontrados fora do Baixo Amazonas, por outro lado foram elaborados principalmente (segundo análises de difração de raios $\mathrm{X}$ ) em serpentina, além de vários minerais semipreciosos, como amethista, peridoto, aventurina, turquesa, cornelian, nefrita, etc. (Boomert, 1987). Os trabalhos quando citam jade dão a entender a nefrita. Estudo mineralógico e químico atual dos muiraquitãs está sendo publicado nesta revista por Costa et al. (2002).

\section{Aspectos Físicos Gerais Segundo a Literatura}

Os muiraquitãs apresentam-se em vários matizes de verde, desde o branco ao esverdeado, verde amarelado, azeitonado, leitoso, até o verde escuro, quase preto. A cor dominante é verde clara, com "veias" de tonalidade ligeiramente mais escura ou mais clara, que é característica de jade, e a mais apreciada (Fig. 1). A dureza é elevada (em geral de 5 a 6 , até 7), quando em jade, quartzo, feldspato, amazonita, diorito, rocha básica ou granito ou baixa, quando em talco (talcoxisto ou esteatito) ou serpentina. Entre os historiadores, pesquisadores e cronistras que se preocuparam com os muiraquitãs, apenas Koehler-Asseburg (1951) e Boomert (1987) fazem considerações sobre suas características físicas (cor, dureza, densidade, dimensões, talhe, homogeneidade do material, transparência, etc.). Os muiraquitãs tem comprimento de 44 a $64 \mathrm{~mm}$, largura de 22 a $57 \mathrm{~mm} \mathrm{e}$ espessura de 15 a $19 \mathrm{~mm}$. O material é geralmente microcristalino, ligeiramente fibroso, visível apenas localmente no artefato, lembrando a feição de nó-depau, o que levou a interpretar a etimologia da palavra muiraquitã, como nó-de-pau. Detalhes morfológicos, físicos, mineralógicos e químicos para as peças do MPEG e MAE são apresentados por Costa et al. (2002).

\section{A Arte de Esculpir os Muiraquitãs}

Os principais passos sugeridos para a confecção de um muiraquitã estão indicados na Figura 4. Os elementos corporais externos da rã são indicados através de incisões sobre a pedra. Os artefatos ainda apresentam os dois furos laterais no lado posterior, não vísiveis pela parte frontal. Para Barata (1954) esses furos são características fundamentais para 
distinguir os muiraquitãs verdadeiros dos falsos. As quatro peças do acervo do MPEG e aquela da profa. Amarilis Tupiassu de Belém se enquadram na classificação de Barata (1954), enquanto as 5 peças do MAE o enquadramento é apenas parcial. As formas batraquianas encontradas além do domínio do Baixo Amazonas apresentam um design distinto $\mathrm{e}$ geralmente são muito menos elaboradas do que aquelas dessa região (Boomert, 1987).

As populações pré-colombinas da Amazônia produziram artefatos em pedra, ossos e cerâmica, que, entretanto, não tinham o acabamento esmerado, observado nos muiraquitãs. Antrópologos e arqueólogos ainda não conseguiram entender como esses povos poderiam, com instrumentos rudimentares e improvisados, chegarem a produtos tão bem esculpidos, elaborados e polidos. Eles supõem que para perfurar e esculpir a pedra, os indios utilizavam procedimentos engenhosos, e que os produtos finais eram frutos de muito paciência e habilidade. Eles estavam na verdade elaborando preciosos amuletos a partir de pedra rara.. Barata (1954) encontrou em sitios arqueológicos vários instrumentos líticos como serras, pedras para polimento e raspadores (Fig. 5), que poderiam ter sido utilizados para confecção dos muiraquitãs. Rodrigues (1899) imagina que, para fazer os furos laterais, utilizavam procedimento semlhante ao dos índios

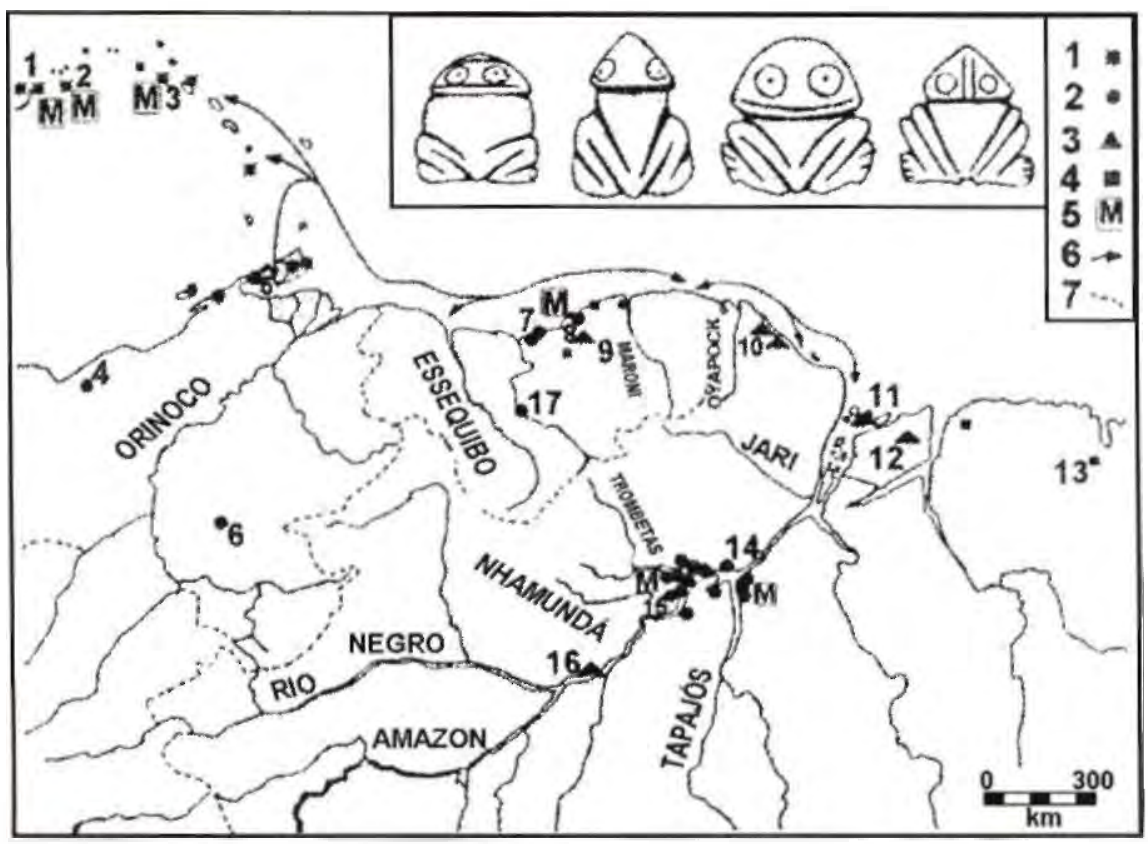

Figura 3. Localização das regiões onde os muiraquitãs c outras formas batraquianas teriam sido encontrados, segundo Boomert (1987).. 
Uaupés. Estes com auxílio de uma varinha de grela da pacova sororoca (Ucrania Amazonica) e com areia fina e água, prendendo-se a pedra entre os dedos polegar e indicador de um dos pés e fazendo-a girar entre as palmas das mãos, com habilidade, paciência e tempo, conseguiam perfurar. Pelo acabamento apresentado pelos muiraquitãs, supõe-se que a eles dedicaram-se os melhores artesãos da época, já que tinham a tarefa de esculpir um artefato (amuleto) para uma finalidade muito especial a partir de uma pedra rara e dura.

\section{Principais Centros de Confeç̧ão}

A maioria dos pesquisadores acredita que os muiraquitãs não foram confeccionados na região onde foram encontradas, Mas Barata (1954), como mencionado anteriormente, faz referência a ocorrência de sitios arqueológicos às proximidades de Santarém contendo fabulosos instrumentos em pedra (serras, pedras de polimento e raspadores) adequados à confecção de artefatos líticos. Porém nenhum muiraquitã sensu stricto foi aí encontrado. As pesquisas arqueológicas à época de Barata mostravam que os Tapajó não utilizavam nefrita ou jadeita em seus trabalhos líticos. Nenhum muiraquitã foi encontrado em Santarém e adjacências em condições de comprovar uma fabricação de proveniência local (Barata, 1954). Esses argumentos, por outro lado, não são convincentes para eximir os índios da capacidade de elaborar com os engenhos da época, peças artisticamente tão bem trabalhadas, necessitando tão somente de habilidade, paciência e tempo, e obviamente um objetivo maior, um amuleto. Admitir elaboração asiática e chegada à Amazônia através de movimentos de povos e troca, como evocou Rodrigues (1875), é desmerecer a capacidade dos povos que habitavam a região. Além disso não são reportados muiraquitãs batraquianos ou similares em nefrita na Ásia. Há obviamente muito artefatos em pedras com motivos batraquianos, porém com design completamente distinto dos muiraquitãs. Ao mesmo tempo Rodrigues (1875) contradiz-se ao relatar que no Baixo Nhamundá, local das Icamiabas (as Amazonas de Orellana), encontrara fragmentos de rochas e lascas do material com que eram confeccionados os muiraquitãs. As lendas também aludem procedência local, ao contarem que os muiraquitãs eram magicamente elaborados a partir da lama de um lago da região do Yamundá (Figs. 3 e 6) ou que os muiraquitãs eram formas vivas encontradas nos lagos dessa região. Alguns europeus, nos primeiros séculos da conquista, espalharam que muiraquitãs já existiam moles embaixo d'água no lago, e que, ao serem retirados da água, endureciam em contato com o ar. A procedência amazônica é contada por Ferreira (1885): este rio demora distante do Amazonas 15 leguas subindo-se pelo lado direito do Trombetas. Nas suas cabeceiras existe um lago, onde se encontram umas pedras verdes de varios feitios, que se suppõe serem formadas de um barro que petrifica-se n'agua. Mesmo sendo lendas, reforçam a proveniência local. 


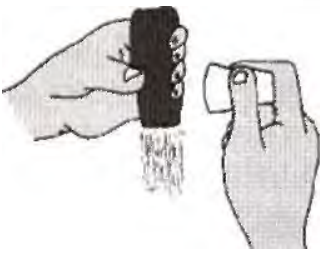

$1^{\text {a }}$ Etapa: Desbaste

O mineral era desbastado com auxílio do raspador, confeccionado geralmente em quartzo. Nessa etapa já se obtinha a forma escolhida com as reais dimensóes.

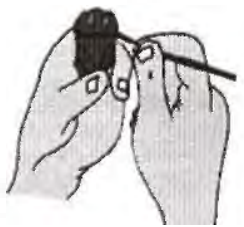

$3^{\text {a }}$ Etapa:Perfuração dos furos Com auxilio de um objeto pontiagudo (ossos de animais ou mesmo pedaços de minerais ou rochas), os indios marcavan os canais e posteriomente friccionando com água e areia os perfuravam.

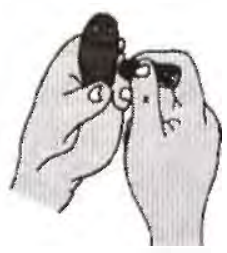

2* Etapa: Entalhes

Com auxilio das serras friccionadas com água e areia, surgem os delicados entalhes formadores dos olhos, pernas e pescoso.

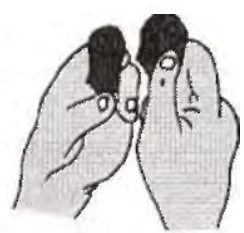

$4^{3}$ Etapa: Polimento

Utilizando a pedra de polir e areia fina os indios, arredondavam as latcrais tos muiraquitàs e depois poliam usando o mesmo processo.

Figura 4. Fases de elaboração de um muiraquitã segundo SILVA et al.(1997).
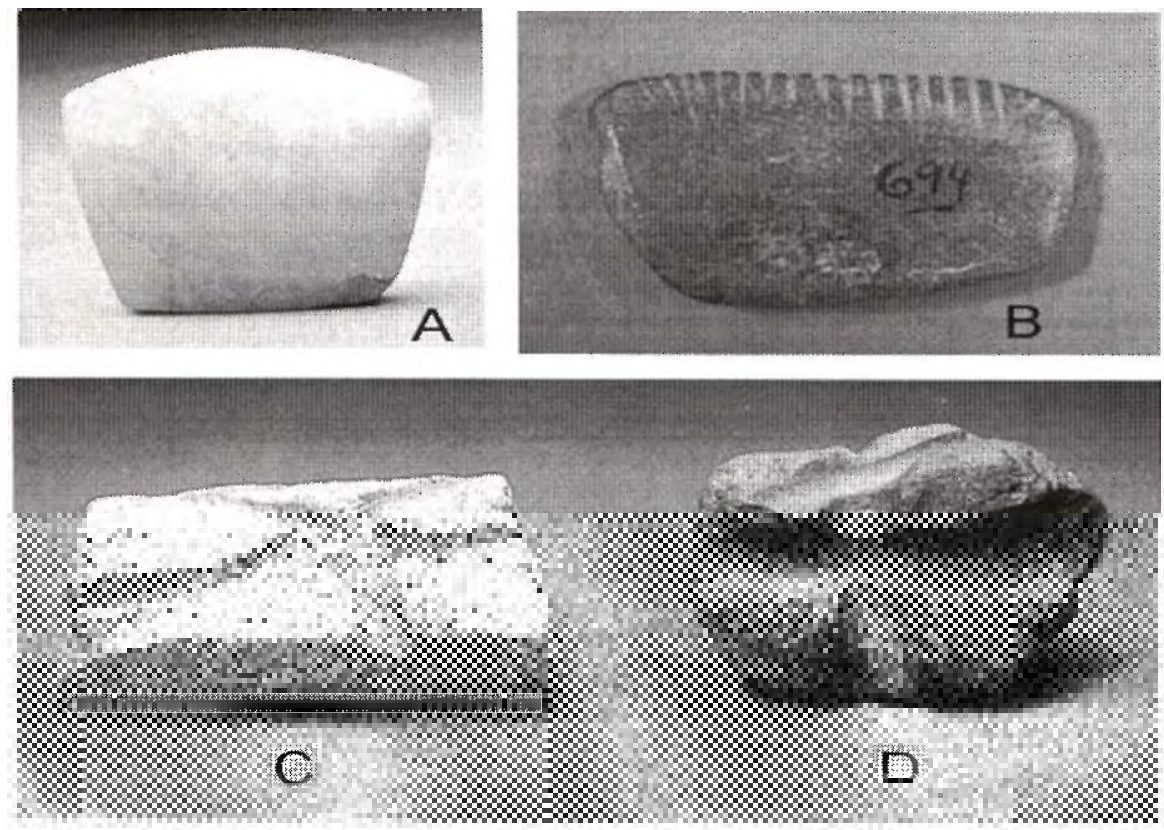

Figura 5. Artefatos em pedra encontrados por BARATA (1954) nos arredores de Santarém que supòs terem sido utilizados para a manufatura de pingentes tipo muiraquitãs. 
Os povos pré-históricos da Amazônia, em especial aqueles do Baixo Amazonas, das culturas Santarém/Tapajó e Konduri, ou seus antecessores, eram capazes de esculpir artefatos em rocha dura como aquela dos muiraquitãs, já que, confeccionaram grande quantidade de artefatos em rocha e mineral tão duros ou mais duros que o jade a nefrita, ou teriam sido estes também confeccionados além das fronteiras amazônicas (?). São exemplos as setas das pontas de flechas, em quartzo (cristal de rocha e calcedônia), muitas delas de esmerado acabamento, embora desprovidas de polimento (que era denecessário) e machadinhos com fino acabamento e polimento; também contas cilindricas bem elaboradas e com polimento (Fig. 2). É possivel, por outro lado, que tenha havido troca, comércio e doaçao de presentes, entre os povos que habitavam não só a atual Amazônia Brasileira, como aqueles da América Central e América do Sul (Koehler-Asseburg, 1951; Boomert, 1987). É difícil imaginar uma única região produtora de muiraquitãs, já que os mesmos tem sido encontrados em vários locais da América Central, embora sem a denominação amazônica e ainda com diferenças na arte final e na composição do material.

É Boomert (1987) que através de trabalho crítico e detalhista, cobrindo toda a região de ocorrência de formas batraquianas em pedras verdes, discute três importantes centros de produção destes artefatos, incluindo os muiraquitãs:

\section{1.) Centro do Baixo Amazonas}

Foi o principal centro de produção de muiraquitãs em rochas verdes. A área de influência ocupava o baixo curso dos rios Nhamundá, Trombetas e Tapajós. Essa extensa região corresponde ao contexto arqueológico dos complexos préhistóricos tardios Konduri e Santarém (Séries Ceramista da Amazônia, estilo inciso e pontilhado), que se estenderam aos tempos históricos e são correlacionáveis às Séries Arauquinoid da bacia do Orinoco e que ainda podem ser correlacionadas com a Tradição Policrômica Marajoara do arquipélago do Marajó. Neste centro os pingentes eram elaborados principalmente em jade nefritico e com estilo próprio. Peças foram encontradas ainda no Suriname, no Marajó (Boomert, 1987). Ihering (1906), quase um século atrás, já deduzia a existência de duas regiões produtoras de jade no Brasil: Baixo Amazonas no Pará e Amargosa na Bahia, confeccionando artefatos muitos distintos entre si. Não se conhece muiraquitãs em Amargosa.

\section{2.) Centro Setentrional do Suriname}

Está associado com o complexo Kwatta da zona costeira central, uma tradição ceramista pré-histórica tardia, um membro da série Arauquinoid. A maioria dos pingentes são batraquianos, com design distinto dos muiraquitãs, feitos de riolitos, seguidos por tremolita, nefrita, quartzo, metabasalto, greisen e laterito (Boomert, 1987). A forma e o design batraquiano variam muito e lembram os espécimes amazônicos. Mas pingentes bem elaborados são raros. Os poucos confecionados em nefrita (tremolita) 
devem representar importações da Amazônia (Boomert, 1987);

\section{3.) Centro Montserrat-Prosperity- Vieques-Antilhas}

Uma grande quantidade de espécimes batraquianos, mais de 1400 , em todos estágios de confecção, encontrados no contexto Saladoid, foram aí encontrados e foram confeccionados em serpentina, ametista, peridoto, aventurina, turquesa, carnelian, nefrita, entre outros (BOOMERT, 1987). Durante os tempos Salaoid deve ter existido uma rede complexa de intercâmbio nas Antilhas, quando houve uma intensa movimentação, em particular, de pedras semi-preciosas e outras matérias-primas, que como ornamentos elaborados, inclusive pedras verdes, ao norte, deslocavam-se para sul, até a costa da América do Sul (Boomert, 1987).

\section{Uso}

Os muiraquitãs eram utilizados principalmente como amuletos

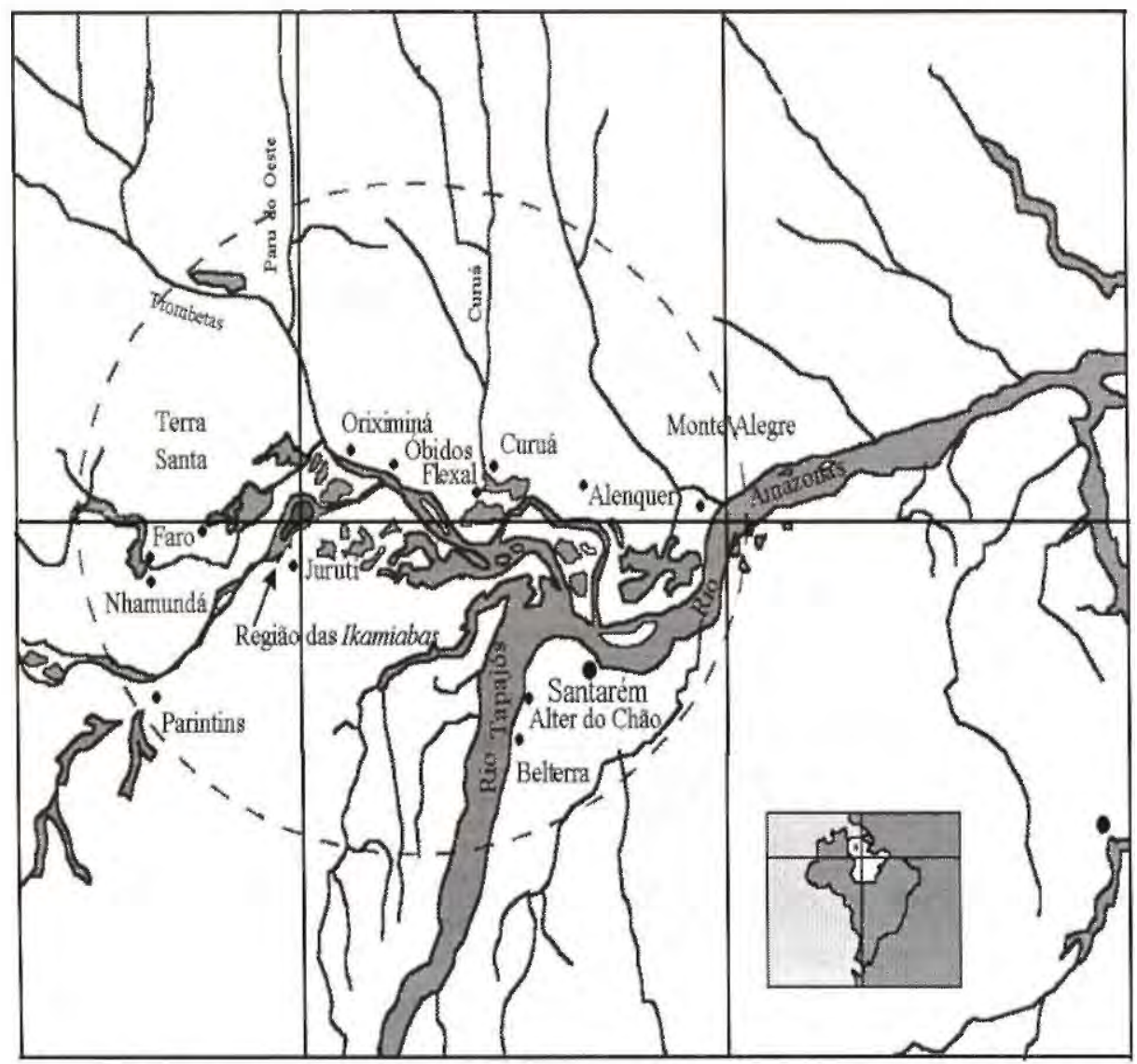

Figura 6. A região do Baixo Amazonas, centro de confeç̧ão e troca de muiraquitãs bem como das guerreiras Amazonas ou Icamiabas (Ikamiabas) e dos complexos Tapajó e Kunduri . 
(pingentes), ainda ao tempo quando eram relatados apenas como pedras verdes, como mostram os relatos da maioria dos historiadores e pesquisadores:

De La Condamine, no século XVIII, já menciona que as pedras verdes (os muiraquitãs) eram utilizados sob a forma de pendente peitoral (De La Condamine, 1992).

Martius (1867) cita uso como Halsschmuck (colar) com força de amuleto: "Diese Steine sind uebrigens nicht das einzige Amulet, welches sie gegen Krankheiten, Schlangenbiss und andere Übel am Halse tragen. Gleiche Kräfte schreiben sie dem Muraqué-ità, einem aus dem Ruecken der grossen Flussmuschel geschnittenen, unförmlichn Halsschmucke, der Perlmutter oder irgend einem grossen, abgerundeten Fischknochen zu". É seguido por Netto (1885), que menciona o uso pelos caciques.

Para Heriarte (1874) eram pedras de grande estima, utilizadas como dote e para compra de mulheres para o casamento, escravos e cães de caça.

Rodrigues (1875) relata que velho indio tapuya possuia um muiraquitã, legado de seu pai, guardado como precioso tesouro, que não trocava e nem vendia por conter virtudes imaginárias, protegendo-o de certas moléstias como epilepsia, esquinência, cólicas, e além de ter virtudes e encantos; traziam-no pendurado ao pescoço.

Embora Frei Gaspar de Carvajal durante a expedição de Orellana, não mencione as pedras verdes, Rodrigues (1899) acredita que as Ikamiabas já usavam os muiraquitãs. Para ele as Icamiabas eram tribo indigena com feições femininas, onde as mulheres auxiliavam nas batalhas, e Orellana intencionalmente confundira com as Amazonas da mitologia grega.

Koehler-Asseburg (1951) diz ainda: "Estes objetos, dotados de virtudes maravilhosas, inatas ou adquiridas, constituiam (e constituem) amuletos que, por tal motivo pertenciam à magia. Todavia, para o seu pleno efeito, deviam ser impessoais, inconscientes e portáteis".

Nimuendaju (1948) acredita que eram utilizados como jóias apostas a testa, suspensos por cordéis que atravessavam os furos laterais. Barata (1954) refuta esta idéia, pois a grande dimensão de várias peças seria inconveniente para uso na testa. Fernandes (1990) informa que índios Pariukur do rio Arukuá do Estado do Pará usavam muiraquitã pendurado no nariz, e que quando morriam eram enterrados com o mesmo. Rodrigues (1899) conheceu uma velha india da tribo Tapuyus (Tapajó) com cerca de 120 anos, que contara, que quando era menina trocavam-se produtos por muiraquitãs no rio Yamundá (Figs. 3 e 6) ou que os muiraquitãs eram usados como amuletos pendurados no pescoço.

Para Boomert (1987) the "green stones formed one of the principal media of intra-as well as interethnic ceremonial exchange throughout the Tropical Forest area of northern South America. Obviously they represent primitive valuables, which were exchange between the elites of the chiefdoms in the Amazon and Orinoco floodplains and between the big men of the tribal communities beyond the major riverine systems of the region. 
The amazon-stones represented highly prestigious items of adornment: they were ways of exhibiting wealth and visual symbols of successful participation in the regional exchange network".

Pelo exposto e pela presença dos furos laterais, caminhos para o cordel, está claro que os muiraquitãs eram pendurados em algum lugar do corpo humano, até como tanga, como enfeites para vaidade, como superstição, ato religioso. Indubitavelmente era um elemento muito estimado, um amuleto, e que provavelmente ao longo dos séculos tenha tido outros usos, como os mencionados anteriores.

\section{Simbolismo da Forma Batraquiana}

Não deixa de ser extraordinário o tributo que o povo Tapajó devotava aos muiraquitãs. A combinação pedra verde (jade) e forma batraquiana não deve ter ocorrida por acaso. Embora os povos Tapajó confeccionassem em pedras muito objetos para diferentes utilidades, apenas os muiraquitãs foram feitos em jade. Entende-se que essa pedra tinha e tem algo de especial, além de sua possivel raridade, como bem descreve Harder (1992). Às pedras verdes, como o jade, em países da Ásia, como a China, e da América Central, são creditadas virtudes medicinais e espirituais, assumindo a função de verdadeiros amuletos. Na Amazônia não poderia ter sido diferente. $\mathrm{O}$ muiraquitã na forma batraquiana poderia estar retratando a fertilidade, já que animais como as rãs tem alto poder de reprodução. A forma geral desses animais também lembra a forma externa do órgão reprodutor feminino e sua localização corporal, o que reforça ainda mais a idéia relativa a fertilidade. A alta fecundidade dos batráquios já era admirada há muito tempo pelos povos antigos. Juntos, cor e forma batraquianas, estariam aludindo à fertilidade na reprodução humana, na época muito importante para formação de guerreiros e agricultores/coletores. Essa analogia entre o muiraquitã (forma batraquina) e a anotomia externa do sexo feminino, como parecem indicar as lendas e ditos populares, já fora identificada por Koehler-Asseburg (1951). E essa correlação entre muiraquitãs e lenda das guerreiras Amazonas, como será mostrada a seguir, não aconteceu por acaso. A cor verde dos batráquios, perpetuada na forma de muiraquitãs, retrataria ainda a cor das águas, mais especificamente do rio Tapajós e dos inúmeros lagos que se estendem pela região, o centro principal da cultura Tapajó; da mesma forma retratava a cor da floresta verdejante. Mata e águas constituindo o mundo dos povos pré-colombinos da região.

Rodrigues (1899) mostra ainda que nas tribos atuais, os batráquios exercem poder místico e respeitoso, fato possivelmente herdado, através dos tempos, dos seus antecessores. A rã e o sapo tem importante papel no mundo mental e na arte de muitas culturas, observado em diferentes regiões da Ásia, Oceania e América. A eles se ligam não só artisticamente, como também lhe atribuem funções boas e más, ou mesmo o papel de verdadeira divindade (Koehler- 
Asseburg, 1951). E nos índios da América do Sul não teria sido diferente, segundo Wassen (1934a; b). Eles os consideram venenosos na alimentação, relacionam o seu coaxar com a chuva e a fertilidade. $\mathrm{O}$ valor não material atribuído aos batráquios, segundo Wassén, surgiu na América, entre os indios, que viviam cercados por eles. Sapos e rãs são animais que se apresentam misteriosos e cheios de predicados mágicos, benéficos e maléficos, para os povos indígenas da Amazônia. Ainda hoje são assim vistos por certos povos ou comunidades. Muitas tribos indígenas brasileiras atuais continuam devotando a esses animais poderes sobrenaturais. Recentemente pajé indigena brasileiro tentou curar o indigenista brasileiro Augusto Rushi que teria sido atingido pelos poderes maléficos de batráquios da Amazônia.

\section{Origem da Matéria-Prima e Aspectos Etnográficos}

Uma das questões mais intrigantes que permanece até hoje, e que surgiu há mais de dois séculos atrás é, qual a procedência do jade utilizado na confecção dos muiraquitãs (pingentes batraquianos) e formas não batraquianas, encontrados na Amazônia, principalmente no Baixo Amazonas e ainda em locais na porção setentrional da América do Sul e Central. Ainda hoje não se dispõe de resposta satisfatória a estas questões, embora muitas explicações tenham sido dadas, algumas bastante imaginativas. Ainda no século passado se sabia que os muiraquitãs eram elaborados em jade, nefritico, além de outros materiais. De todos estes, apenas jade não seria conhecido na Amazônia, nem no resto do Brasil. No final do século dezenove, em 1875 , Fischer $(1880 \mathrm{a} ; \mathrm{b})$, em seu trabalho Nephrit und Jadeit, estudou enúmeros artefatos líticos encontrados em vários sítios arqueológicos da Europa, que eram feitos em jade. Sabendo que jade era desconhecido também na Europa, ele propôs que o mesmo tivesse vindo da Ásia. Era a primeira vez que se aplicava a mineralogia à arqueologia. Esta conclusão promoveu a procura por jade na Europa, tendo sido encontrado imediatamente, invalidando a conclusão de Fischer. Logo depois Fischer (1884) descreve nefrita no Brasil e na Venezuela. Em seguida Barboza Rodrigues publicava seu primeiro trabalho sobre muiraquitãs (Rodrigues, 1899), e ao tomar conhecimento do primeiro trabalho de Fischer, estendeu as mesmas idéias para o jade da Amazônia. $O$ jade aqui teria vindo também da Ásia. E assim escreveu: $O$ muyrakytã é um monumento Asiático deixado em solo Americano por um ou mais povos imigrantes. Essas hipóteses imaginativas baseadas em lendas e na linguística, harmonizadas com a gênese biblica para explicar a corrente migratória da Ásia até a Amazônia, foi duramente criticada. Elas parecem não ter fundamento.

Mas nefrita foi encontrada em várias partes do Brasil, a partir do século XX. Uma revisão bibliográfica recente a esse respeito foi feita por Hoover (sem data) e outra mais antiga de Silva (1917). Jade a nefrita já foi registrado em Baytinga (Amargosa-BA), como seixos rolados e como artefatos 
(Ihering, 1906); Vitória da Conquista-BA (Hoover, sem data); em Cabo Frio no interior do Rio de Janeiro (Silva, sem data) e em Guarapuava no Paraná (Moraes, 1932); em Piumhy de Minas Gerais como machadinhos (Nephritbeile) (Fischer, 1884); Ubatuba-SP como matéria-prima (Franco et al., 1972 ); Olinda-PE (Silva, sem data).

Sobre nefrita na Amazônia, na forma de muiraquitãs, MORAES (1932) acredita que a fonte da matéria-prima encontra-se nos terrenos cristalinos do Pré-Cambriano, tanto ao norte nas cabeceiras dos rios Jari, Paru, Trombetas e Negro como ao sul nos cursos superiores dos rios Tocantins, Xingu, Tapajós e afluentes do Madeira. Para Moraes (1932) Carece pois, de toda importancia, no ponto de vista archeologico, a presença de jade na região do Amazonas. O encontro dessa substancia alli não constitue argumento a favor das hypotheticas incursões de povos euro-asiaticos áquellas paragens, uma vez que ella póde existir em seus depositos originaes no proprio valle amazonico.

Jade nefrítico é encontrado em várias partes do mundo, tanto em ambientes geológicos jovens como no Proterozóico e Arqueano, que estão bem representados no Brasil e na Amazônia. Existe muito jade nefrítico nas Américas incluindo o Canadá e ainda na Austrália, sem mencionar os países asiáticos, onde o jade vem sendo usado desde os tempos históricos (por mais de 2000 anos) até o presente (Harder, 1992; Weise, 1993).

\section{Lendas e Mitos}

Os muiraquitãs da Amazônia estão envoltos em lendas de romântica beleza e que representam a forma de seu povo mostrar o entendimento de seu meio, expressando respeito e admiração aos possiveis poderes sobrenaturais que o regem (Moura \& Silva, 1929; Bezerra, 1985; Borges, 1986; Dieguez \& Silva, 1996; Silva, 1997; Silva et al.,1997). Entre elas destacam-se:

\section{Segundo as Ikamiabas}

Elas eram uma tribo de mulheres guerreiras, sem maridos, as Amazonas de Orellana, que não admitiam entre si a presença masculina e nem a sua aproximação. Manejavam o arco e a flecha com destreza. Para isso queimavam o seio direito das filhas. Uma vez ao ano, nas fontes do rio Jamundá (Nhamundá ou Yamundá) (Fig.7), na serra Yacy-taperê, onde havia um lago formoso, consagrado à lua, o Yacy-uaruá (espelho da lua), nas fontes do rio Jamundá, as Iacamiabas faziam, certa época do ano, uma grande festa em nome de Iacinará (Fig. 8). Pouco antes da meia-noite, quando a lua estava quase a pino, em procissão, dirigiam-se ao lago, tendo nos ombros, potes cheios de perfume, que eram derramados na água para purificá-la. Dançavam, cantavam e depois atiravam-se ao lago para o banho purificador. À meia-noite, quando a lua se refletia na face lisa do lago, após fazer amor com os Guaçaris (homens de tribo indígena especialmente convidados para a festividade), mergulhavam e traziam do fundo do lago um barro mole e verde, ao qual davam a ele formas 


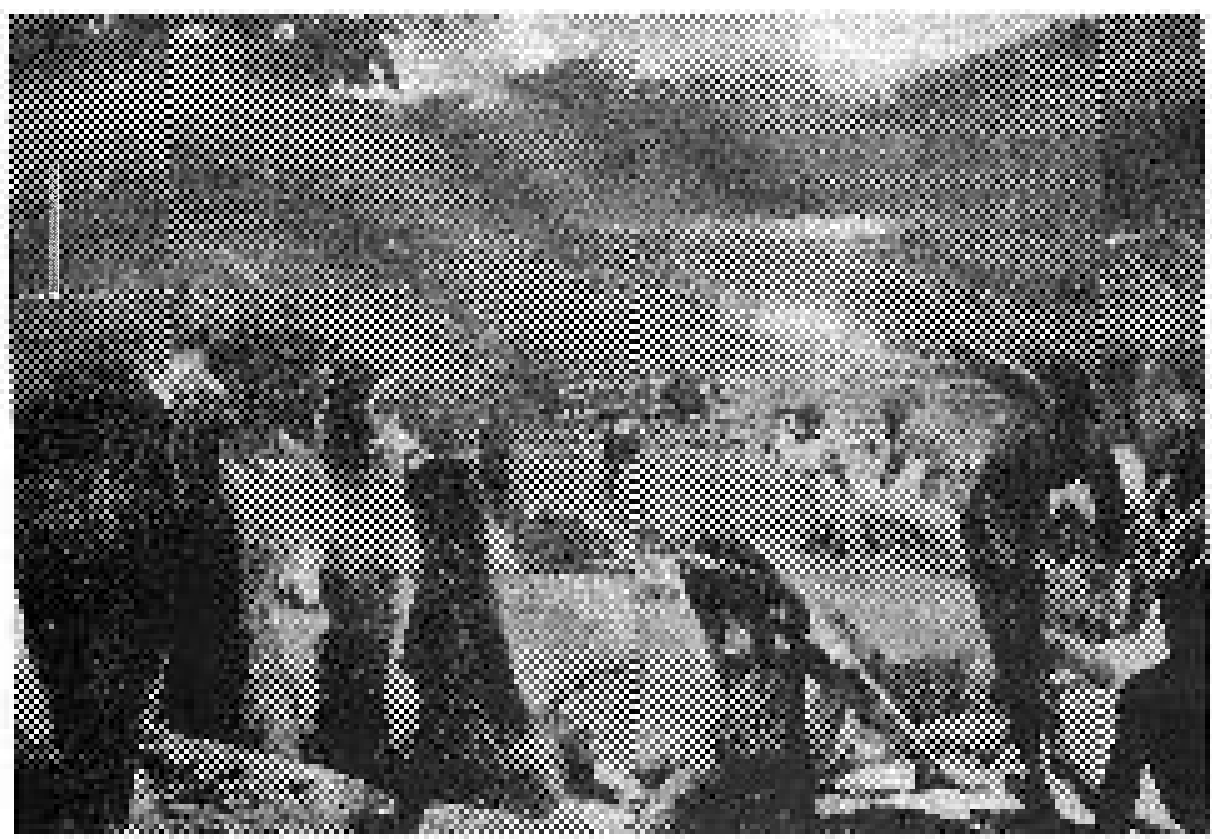

Figura 7. Figura estilizada do possivel lago Espelho da Lua onde as Ikamiabas supostamente realizavam scus rituais, o lacinará. scgundo Moura (1929).

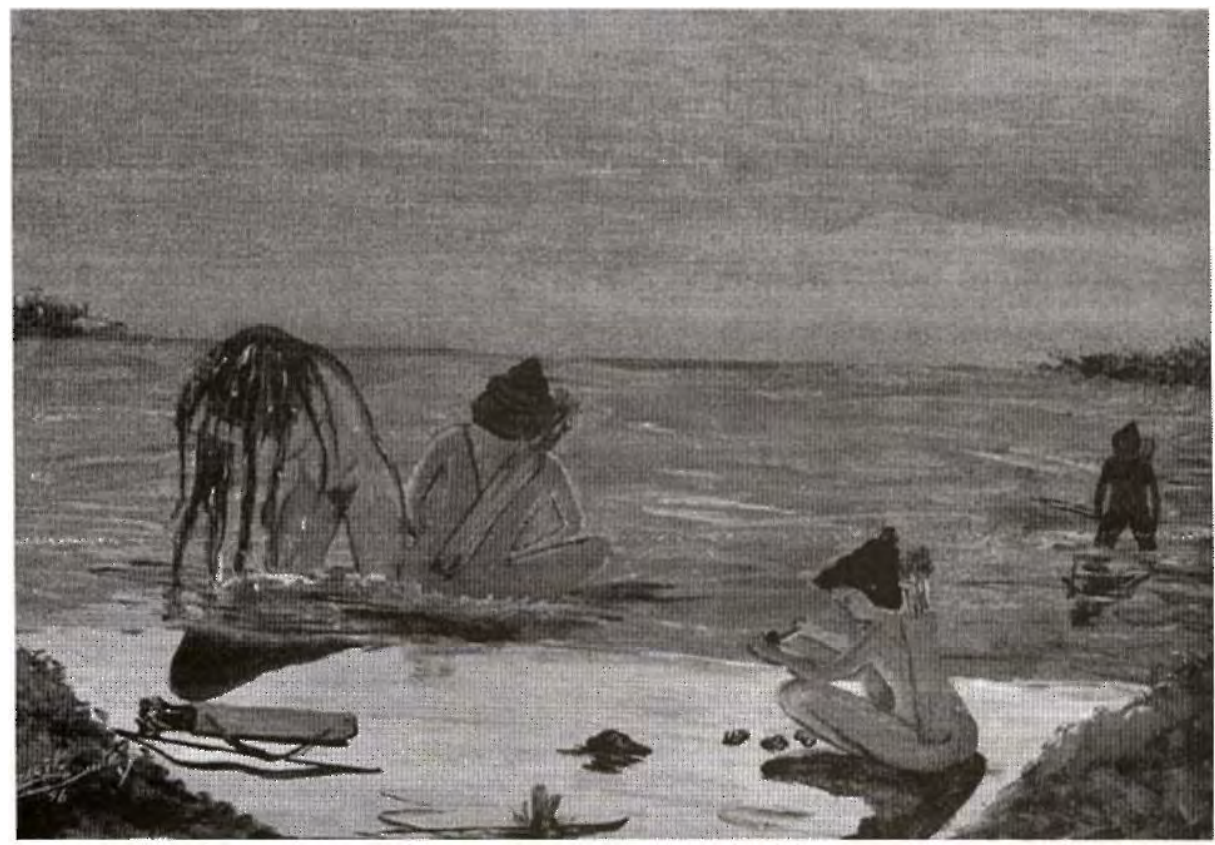

Figura 8. Figura estilizada das Ikamiabas em torno do lago. Modificado de Monteiro (1997) 
batraquianas (os muiraquitãs), que endureciam ao ser retirados da água. Com esses objetos presenteavam os Guaçaris, como amuletos, que eles traziam pendurados ao pescoço.

Outra versão conta que no lago morava a mãe dos Muiraquitãs, e que quando as Amazonas mergulhavam no lago, recebiam dela o muiraquitã. $\mathrm{Na}$ festa do ano seguinte as mulheres que tinham dado a luz meninos os entregavam aos pais, enquanto as filhas permaneciam com as mães.

\section{Segundo os Índios Uaboi}

No lago Yacy-uaruá moravam a mãe dos muiraquitãs e os muiraquitãs, e que só as mulheres podiam apanhálos. Para tal, feriam uma parte do corpo, e deixavam cair sobre aquele que desejavam possuir, uma gota de seu sangue. $\mathrm{O}$ muiraquitã morria e elas facilmente mergulhavam e o apanhavam. Havia muiraquitãs de várias formas e cores, e com eles, as mulheres que tinham dado à luz, recompensavam seus amantes, pais de suas filhas.

\section{Segundo os Índios Uaupés}

Os velhos da tribo Uaupés contam que, antigamente, junto ao rio de mesmo nome, havia um lago onde morava uma anciã conhecida como a mãe do muiraquitã. Certa manhã a anciã saiu pelo mato a passear, transfigurando-se em serpente. Um homem, que havia ido caçar, deparouse com a serpente e a matou. Imediatamente o rio cresceu, inundando tudo e afogando toda a tribo, ficando apenas a marca da pobre velha, o muiraquitã.

\section{Segundo o Livro de Histórias Infantis Vovó Amazônia (Pese, 1981, adaptado).}

Há muitos e muitos anos vivia uma tribo de índios em Tunai, no rio Içana (Alto rio Negro). Viviam felizes da caça, pesca, da agricultura e coleta de frutas. Em tempos de paz, os homens cuidavam do sustento da familia e as mulheres da casa, dos filhos e roçado. $\mathrm{Na}$ guerra, eles defendiam a taba, e elas limpavam as armas, cuidavam dos idosos e das crianças que ficavam. Quando os homens voltavam da luta, encontravam o remédio milagroso para curar as feridas e a rede de tucum para embalar o corpo cansado. As índias eram delicadas e dóceis, faziam tudo o que os homens mandavam (moquear, preparar cauim, cozinhar bolo de milho, etc.). O chefe do tribo, Izi, neto do Sol, considerado sábio e divino, ditava as leis, severas, principalmente para as mulheres, que eram tratadas entre eles sem grande consideração. Essas leis proibiam as mulheres até de participarem no culto de seus deuses e de ouvir os sons da orquesta sagrada (pirei). Certo dia Izi com seus homens subiu a montanha para lhes apresentar as novas leis. Algumas índias não contiveram a curiosidade, e foram espiar. Foram flagradas, e como castigo, o chefe transformou-as em estátuas de pedra. Vendo assim as companheiras, as outras índias ficaram tristes, indignadas e passaram a chorar e clamar por vingança. Enquanto os índios construíam um templo mais distante, onde as mulheres não podiam ir, surgia uma india destemida, Naruna, 
disposta a comandar a vigança. Conclamou as companheiras a abandonar os homens, pois só assim eles iriam sentir a sua falta, pois eram elas que preparavam a comida, teciam as redes que dormiam, carregavam as armas, cuidavam das crianças. - E que fazem eles? Desprezam-nos! Decidiram ir embora e viver sozinhas, numa terra só delas, em que nenhum homem pudesse mandar. - $\mathrm{E}$ os filhos homens, vão crescer! -, concluiram outras, o que fazer? Decidiram deixálos na aldeia, à própria sorte, a espera dos pais. Levaram apenas as meninas. $\mathrm{E}$ assim em várias canoas desceram o rio Içana, entraram no rio Negro e passaram muitas de suas cachoeiras. Abandonaram o rio e entraram na mata, e depois de muito andar, encontram um grande rio, que se abria formando lagoas e lagoinhas, com colinas verdejantes. Decidiram ali ficar, e batizaram o lugar de IaciTaperê (serra da Lua). Junto à colina havia um lago, que denominaram de Iaci-Uaruá (espelho da lua). E ali nasceu a tribo das cunhatãs teco-imãs (mulheres que vivem sem homem). Por sua vez quando os índios voltaram a tribo, encontraram apenas os meninos, que lhes contaram o que havia acontecido. Só assim compreenderam que foram injustos com suas mulheres. Sairam imediatamente ao encalço delas. Depois de muitos dias de caminhada encontraram as companheiras naquela beleza de paisagem colinosa e lacustre. Foi em vão a tentativa de fazerem as pazes e de retornarem à taba, mesmo prometendo tudo o que elas quisessem. Mas tanto imploraram que chegaram a um entendimento. Os maridos viveriam com elas alguns dias por ano. Quando os filhos nacessem, entregariam os meninos aos pais e ficariam com as meninas. Nesse caso, dariam a eles um amuleto, o muiraquitã. No lago vivia um infinidade de peixinhos de várias cores. Eles eram denominados de muiraquitãs. Quando chegava a época dos homens visitá-las, as cunhatãs golpeavam-se e deixavam cair na água o próprio sangue ainda quente. Em contato com o sangue, os peixinhos encantavam-se, transformando-se em pedras de vários feitios, conservando, entretanto a própria cor. As indias então mergulhavam e iam apanhar o precioso amuleto no fundo do lago, e o ofereciam aos pais de suas filhas. Essa pedra, por isso, ficou simbolizando a paz e a felicidade.

\section{Conclusões}

Os muiraquitãs em sua forma batraquiana, confecionado em rocha verde, são um artefato arqueológico real. Sua história por outro lado está envolta em lendas e mitos, que tem um cunho eminentemente amazônico, do Baixo Amazonas, a terra da lenda das Amazonas de Orellana, das Ikamiabas. São artefatos cuidadosamente esculpidos, em mineral ou rocha verde, normalmente jade nefritico, que tinha um grande valor simbólico, usado para vários fins, mas principalmente como amuleto. Formas similares foram fabricadas além das fronteiras do Baixo Amazonas, até a região do Caribe, mas aparentemente não tinham o 
simbolismo que tinha o muiraquitã, além de não terem a perfeição destes. Mas os povos Além-Amazônicos sabiam de sua existência, e os utilizavam como intercâmbio. A matéria-prima era de origem amazônica ou mesmo da América Central, Caribe, Antilhas e de outras regiões de paises amazônicos vizinhos ao Brasil. Por sua vez jade a jadeíta não é conhecido na Amazônia e nem no Caribe e nem nas Antilhas, mas tem sido encontrado com frequência na América Central (Guatemala, México) em sítios arqueológicos e em fontes geológicas (Gendron, 1999; Johnson \& Harlow, 1999). Assim os muiraquitas,

confeccionados principalmente em jade nefritico, são expressões artísticas próprias dos povos que habitavam a região do Baixo Amazonas e não artefatos importados durante a imigração de povos préhistóricos da Ásia para as Américas. Nesta regiao habitavam, como mencionado anteriormente, povos que desenvolveram a melhor expressao da arte ceramista, como os Santarém/ Tapajó e Marajoara, que certamente teria sido capazes de elaborar objetos em pedra como os muiraquitas.

\section{Agradecimentos}

Ao $\mathrm{CNPq}$ pelo apoio financeiro (Proc. 520.041/95) e a CAPES pela concessão de bolsas de estudos; ao Museu Paraense Emílio GoeldiMPEG, em Belém-PA, através das pesquisadoras Vera Lúcia Calandrini Guapindaia e Edith Pereira, pelo apoio aos nos permitir acesso às suas valiosas peças de muiraquitãs. Ao
Museu de Arqueologia e EtnologiaMAE da Universidade de São Paulo, que através de sua entao diretora, Dra. Sílvia Maranca e seu colaborador Dr. Eduardo Goes Neves, nos receberam com distinção e atenção e nos deram acesso aos muiraquitãs do MAE. Ao prof. Dr. Raimundo N. N. Villas, do Centro de Geociências/UFPa, que também nos levou até a peça da Profa. Amarilis Tupiassu.

\section{Bibliografia citada}

Barata, F. 1954. O muiraquitã e as contas dos Tapajó. Revista do Museu Paulista, 8: 229-252.

Barata, F. s/d. Arqueologia-As Artes Plásticas no Brasil. Rio de Janeiro: Editora Tecnoprint S.A., 151p.

Bezerra. A M. 1985. Lendas e mitos da Amazônia. Belém, DEMEC, 102p.

Boomert, A. 1987. Gifts of the Amazons; "green stone" pendants and beads as items of ceremonial exchange in Amazonia and the Caribbean. Antropologica, 67:33-54.

Borges, R. 1986. Muiraquità. In: Borges, R. (Ed.) Vivência Amazônica. Belém, Ediçoes CEJUP, p.629-630.

Costa, M.L.; Silva, A.; Angélica, R.S.; Pollmann, H;; Schukmann, W. 2000. Muyrakytã ou muiraquità: um talismã arqueológico em jade procedene da Amazônia: aspectos físicos, mineralogia, composição química $e$ sua importância etnográfica-geológica. Acta Amazonia: 32( 3)

De La Condamine, M. 1944. "Viagem na America Meridional descendo o rio das Amazonas". Biblioteca Brasileira de Cultura, No. 1, Rio.

De La Condamine, M. 1992. Viagem pela Amazonas 1735-1745.Tradução de Maria Helena Franco Martins. Original: Voyage sur l'Amazone. Rio de Janeiro: Nova Fronteira; São Paulo: EDUSP, 156 p.

Dieguez, F.; Silva, C.E.L. da, 1996, Civilização 
perdida da Amazónia. Super Interessante, 10(6):52-55.

Fernandez, G.1990. As populações indigenas da Amazônia. Revista Trimestral do Instituto Histório e Geográfico Brasileiro. Parte I, vol. L, 358p.

Ferreira, F.I. 1885. Diccionario Geographico das Minas do Brazil. Rio de Janeiro, Imprensa Nacional, 754p.

Ferreira, A.B.H. 1997. Dicionário da Lingua Portuguesa no Brasil - Novo Dicionário Aurélio.

Fischer, H. 1880 a. Ueber die Herkunft der sogennanten Amazonensteine, sowie ueber das fabelhafte Amazonenvolk selbst. Archiv fuer Anthropologie, 12:7-27.

Fischer, H.. 1880 b. Nephrit und Jadeit nach ihren mineralogischen Eigenschaften sowie nach ihrer urgeschichtlichen und ethnographischen Bedeutung. Stuttgart, p.77.

Fischer, H. 1884. Ueber Nephritbeile aus Brasilien und Venezuela. Neues,Jahrbuch fuer Mineralogie, Geologie und Paleontologie, Stuttgart, 2, 214-217.

Franco, R.R.; Leprevost, A.; Bigarella, J.J.; Bolsanello, A.1972. Minerais do BrasilMinerals of Brazil, São Paulo, USP, 3 vols., p.331 and 344 .

Gendron, F. 1999. Le jade-jadeite du Guatemala-Archeologie d'une redecouverte. $R e$ vue de Gemmologie, 136:36-43.

Harder, H. von. 1992, Vom Steinbeil bis zur Smarag-Jade ("Imperial-Jade"). Der Aufschluss, 43:65-82.

Heriarte, M. de. 1874. Descrição do estado do Maranhão, Parả, Gurupá e rio das Amazonas. Vienna d'Austria, Ed. Do Barao de Porto Seguro, 37p.

Hoover, D.B., sem data. Sources of jade in Brazil. Unpublished report ("Bulletin of the Friends of Jade"), Springfield, Missouri, 10p.

Ihering, H, von. 1904. Archeologia comparativa do Brasil. Revista do Museu Paulista, vol. VI, São Paulo, p.519-583

Ihering, H. von. 1906, Ueber das natuerliche Vorkommen von Neprit in Brasilien. In: Int. Amerikanisten-Kongress, 14,
Stuttgart, 1904, Verlag von W. Kohlhammen, vol.2:507-515.

Johnson, C.A.; Harlow, G.E.1999. Guatemala jadeitites and albitites were formed by deuterium-rich serpentinizing fluids deep within a subduction zone. Geology, 27:629-632.

Koehler-Asseburg, I. 1951, O problema do muiraquità. Revista do Museu Paulista, 5:199-220.

Monteiro, W.1997. Lendas e mitos do Pará. Nosso Pará, 4:24-25.

Moraes, L.J. de. 1932. Sobre o jade no Brasil. Anais da Academia Brasileira de Ciências, 4(2): 63-66.

Moura, I.; Silva, E. 1929. Muira-k-ità - uma lenda amasonica. In: Carinhas, T. (Ed.) Album da Colonia Portuguesa no Brasil. Carinhas \& ClA Ltda., 615p.

Netto, L. 1885. Investigação sobre a arqueologia brasileira. São Paulo, Arquivo do Museu Nacional, vol.6, 529p.

Nimuendaju, C. 1948. Os tapajó. Publicações avulsas do Museu Paraense Emilio Goeldi, vol. $10,105 p$.

Palmatary, H.C. 1960. The Archaeology of the Lower Tapajós Valley, Brazil. Transactions of the American Philosophical Society, New Series vol. 50 part. 3, Philadelphia, 243 p.

Pese, R. 1981. Vovó Amazônia está contando - As amazonas e o muiraquitã. Editora Grafisa, Belém, p. 43-58.

Rodrigues, B. 1875. Exploração do Valle do Amazonas. Rio de Janeiro, Typographia Nacional, 54p.

Rodrigues, B. 1899. O Muyrakytã e os Ídolos Simbólicos. $2^{4}$ ed., vol.1, Rio de Janeiro, Imprensa Nacional, 210p.

Silva, A.C.R.L. 1997. O muyrakytã (o muiraquitã). Centro de Geociências, Curso de Especialização em Gemologia, UFPa, Belém, 35p.

Silva, A.C.R.L.; Costa, M.L.; Angelica, R.S. 1997. O muiraquitã (muirakytã). REMRevista da Escola de Minas, 51(2):24-29.

Silva, A.C.S. da 1917. Nephrite in Brazil. Proceedings $19^{\text {th }}$. International Congress of 
Americanists, 1915, p. 229-235

Simões, A.C. 1976. Nota sobre dus pontas-deprojetil da bacia do Tapajós (Pará). Boletim doMuseu Paraense Emilio Goeldi, Antropologia, 62: 1-15.

Smith, H.H. 1879. Brazil - The Amazon and the Coast. Charles Scribner, New York, $644 \mathrm{p}$.

Martius, C.F.P. von. 1867. Beitraege zur Ethnographie und Sprachenkunde Amerika's, zumal Brasiliens. 2 vols. Leipzig.

Wassen, H.. 1934 a. The frog-motive among the South American Indians: omamental studies. Anthropos, 29:319-370.

Wassen. H.. 1934 b. The frog in Indian mythology and imaginative world. Anthropos, 29:613-658.

Weise, C. 1993. Jade, das Juwel des Himmels. Die Jade - Kunst in der Qing-Dynastie 1644-1911. Weise, Muenchen, 40p.

\section{Aceito para publicação em 04/06/2002}

